\title{
VZNIK ČESKOSLOVENSKÉHO EGYPTOLOGICKÉHO ÚSTAVU. STŘET MEZI ČSAV A FF UK*
}

\author{
ADÉLA JƯNOVÁ MACKOVÁ
}

\section{FOUNDATION OF THE CZECHOSLOVAK INSTITUTE OF EGYPTOLOGY. CONFLICT BETWEEN THE CZECHOSLOVAK ACADEMY OF SCIENCES AND THE FACULTY OF ARTS OF THE CHARLES UNIVERSITY}

This study presents the progress of negotiations related to the establishment of the Czechoslovak Institute of Egyptology in 1956. At that time, František Lexa and Zbyněk Žába had travelled as part of a cultural delegation to Egypt and managed to secure from their Egyptian counterparts a preliminary consent to the foundation of the Institute. The study traces the development of this initiative until 1960, when the Institute was established as an independent research body within the Faculty of Arts of the Charles University. The author focuses on the institutional underpinnings of the Institute (its relations to both the Charles University and the Czechoslovak Academy of Sciences) and on issues related to the scope of its scientific activities.

Keywords: František Lexa - Zbyněk Žába - Czechoslovak Institute of Egyptology - Czechoslovak Academy of Sciences - Faculty of Arts of the Charles University

DOI: $10.14712 / 23365730.2018 .13$

Egyptologický ústav v Praze vznikl až v roce 1958, ale tradice egyptologie jako oboru přednášeného na univerzitě sahá už do roku 1913, kdy ji na německé univerzitě začal přednášet soukromý docent pro egyptologii Nathaniel Reich. ${ }^{1}$ V roce 1919 byly konány první přednášky na české univerzitě, které vedl přední český egyptolog první poloviny dvacátého století, František Lexa. ${ }^{2}$ V roce 1925 byl založen egyptologický seminář na české filozo-

* Studie vznikla v rámci projektu GA ČR 13-09541S Univerzita Karlova a Československá akademie věd. Instituce vědy a vysokoškolské vzdělanosti v proměnách politiky a společnosti v letech 1945-1968.

1 Viz seznam přednášek pro zimní semestr r. 1914/15 na německé univerzitě: Ordnung der Vorlesungen an der k. $k$. deutschen Karl-Ferdinands-Universität zu Prag im Wintersemester 1914/15. Životním osudům a vědecké činnosti Nathaniela Reicha se ve svých pracích věnoval egyptolog Wolf B. Oerter, Die Ägyptologie an den Prager Universitäten 1882-1945, Prag 2010, s. 44, 96n., 105n., 116-121. V roce 1919 skončily na německé univerzitě přednášky z oboru egyptologie s odchodem Nathaniela Reicha do Vídně a byly na německé univerzitě obnoveny až v roce 1930 resp. 1938 s habilitací Ludwiga Keimera, k tomu viz W. B. Oerter, Die Ägyptologie an den Prager Universitäten, s. 47-63.

2 František Lexa (1876-1960), český egyptolog, zakladatel československé egyptologie, v roce 1925 založil Egyptologický seminář na FF UK, od roku 1958 byl ředitelem Československého egyptologického ústavu. Viz Ladislav BAREš, Život Františka Lexy, in: František Lexa, zakladatel české egyptologie, Acta Universitatis Carolinae - Philologica 4, 1984, s. 21-40; Adéla JŮnová MAcKovÁ, Egyptolog na cestách. Cesta profesora Františka Lexy do Egypta v letech 1930/1931, in: Adéla Jůnová Macková - Hana Navrátilová - Libor Jůn Lucie Storchová - Hana Havlůjová, Českoslovenští vědci v Orientu, I, Praha 2012, s. 283-324. 
fické fakultě. V pozici soukromého docenta vyučoval v semináři též Jaroslav Černý, ${ }^{3}$ který po válce odešel do Velké Británie, kde působil jako egyptolog na univerzitách v Londýně a v Oxfordu.

Asistentem a pokračovatelem Františka Lexy se po dokončení studií v roce 1949 stal Zbyněk Žába. ${ }^{4}$ Egyptologie byla v té době již etablovaným oborem a politický vývoj v Československu spolu s událostmi v Egyptě v polovině padesátých let př́mo vybízely $\mathrm{k}$ dalšímu rozvoji oboustranných kulturních styků, tedy i egyptologického bádání. Pružně se rozvíjející kontakty hospodářské, především spojený export sovětského a československého zbrojního průmyslu do Egypta, ${ }^{5}$ a následná účast obou egyptologů na oficiální delegaci vyslané do Káhiry za účelem navázání kulturních styků (kdy se ovšem tato ryze kulturní delegace vydala i na prohlídku průmyslových a zbrojních závodů) pak samožrejmě urychlily následná jednání v Československu. ${ }^{6}$

V záríi 1956 odeslal Žába návrh na realizaci kulturní dohody, v němž z hlediska rozvoje egyptologie a kromě spolupráce na egyptských výzkumných projektech, jako byl dlouhodobě připravovaný průzkum Núbie (v důsledku stavby Asuánské přehrady byla velká část této oblasti zatopena vodou) či výzkum v deltě Nilu, zmínil i možnost zrrízení egyptologického pracoviště v Káhiře: „Celkem mimo tyto návrhy dávám na uváženou, zda by nebylo možno jednou zř́dit v Egyptě Československý egyptologický institut [...]. Byl by to první institut vědeckýv Egyptě některé slovanské země a jistě by neobyčejně prospěl propagaci naši vědy na Předním východé." "7

Ve své zprávě pro ministerstvo školství a kultury z 19. prosince 1956 již Žába podtrhl důležitost zamýšleného egyptologického ústavu v rámci dlouhodobé kulturní spolupráce Československa a Egypta: „Po zralém uvážení a s plným souhlasem akademika F. Lexy jsem v poslednim bodě svých připominek ke konkrétní náplni prvniho roku československé kulturní dohody s Egyptem navrhl zrrizení československého egyptologického ústavu v Káhiře. Vycházel jsem tehdy z potřeb naši egyptologie, která za nynějšiho stavu bádánív tomto oboru nezbytně potřebuje př́mý styk a spolupráci s Egyptem, nemá-li zůstat daleko pozadu za světovým prüměrem nyní, kdy dosavadní zpưsoby práce na základě nepř́mého materiálu, náhodně publikovaného, nepostačuji už k ř rešení dnešnich úkolù. “8 Egyptologické praco-

3 Jaroslav Černý (1898-1970), český egyptolog, působil jako soukromý docent na FF UK, po druhé světové válce odešel do Londýna a následně do Oxfordu. Viz Hana NAVRÁTILOVÁ, Jaroslav Černý, egyptolog na cestách nejen po Egyptě, in: A. Jůnová Macková - H. Navrátilová - L. Jůn - L. Storchová - H. Havlůjová, Českoslovenští vědci, s. 349-392; Jiřina RưžovÁ, Jaroslav Černý. Písař Mista pravdy, Praha 2010.

4 Zbyněk Žába (1917-1971), český egyptolog, ředitel Československého egyptologického ústavu od roku 1960 , vedl československou akci na záchranu egyptských památek UNESCO 1960-1965. Viz Adéla JŮNOvÁ MACKOvÁ, Druhá cesta Františka Lexy do Egypta. Československá kulturni delegace v Egyptě v roce 1956, in: A. Jůnová Macková - H. Navrátilová - L. Jůn - L. Storchová - H. Havlůjová, Českoslovenští vědci, s. 325-348.

5 Petr ZídEK - Karel SieBer, Československo a Blizký východ v letech 1948-1989, Praha 2009.

6 Adéla Jưnová Macková, Journey of Czechoslovak Cultural Delegation to Egypt in 1956. „, Cultural Agreement" between Egypt and the Czechoslovak Republic, Acta Filozofické fakulty Západočeské univerzity 3/11, 2012, s. 101-110; TÁŽ - Pavel ONDERKA, Travels of Czechoslovak Egyptologists to Egypt in 1950s, in: titíž (eds.), Crossroads of Egyptology. The Worlds of Jaroslav Černý, Praha 2010, s. 51-58.

7 Archiv Československého egyptologického ústavu (dále AČEgÜ), k. 1, č. j. I/1/1956. Návrh Zbyňka Žáby ze dne 21. září 1956. Materiál a návrh na realisaci kulturní dohody československo-egyptské pro rok 1957 v oboru egyptologie. Př́ípis rukou F. Lexy, souhlas se založením egyptologického ústavu v Egyptě. Jedná se o vůbec první veřejný návrh na založení egyptologického ústavu.

8 AČEgÚ, k. 1, I/4/1956. Návrh na zřízení Československého egyptologického ústavu v Káhiř̌e ze dne 19. 12. 1956. 
viště bylo v rámci tohoto návrhu zamýšleno jako čistě vědecký egyptologický ústav, který se měl zabývat pouze Egyptem starověkým a byl velmi úzce vymezen jak geograficky, tak svým zaměřením a obsazením pracovních pozic (Lexa, Žába a tři studenti). Žába navrhoval za členy ústavu osoby spojené s Filozofickou fakultou Univerzity Karlovy a pravděpodobně od počátku předpokládal, že se ústav stane součástí univerzity. Explicitně se však k problematice začlenění pracoviště do stávajících vědeckých struktur nevyjádřil. ${ }^{9}$

Otázka vzniku, umístění a šíře vědeckého výzkumu se pak staly hlavním střetem mezi ČSAV, respektive Orientálním ústavem, a Filologickou fakultou ${ }^{10}$ Univerzity Karlovy, respektive jejím Egyptologickým seminářem. $Z$ rozboru následujících zápisů schůzí na ministerstvu školství a dochovaných návrhů ke vzniku egyptologického ústavu vypracovaných Zbyňkem Žábou můžeme sledovat pokusy Orientálního ústavu zamezit vzniku nového konkurenčního pracoviště či jej alespoň začlenit do ČSAV, kde by se dostalo pod jeho kontrolu. ČSAV argumentovala svou rolí „nejvyšši vědecké instituce republiky Československé sdružujicí nejvýznamnějši vědecké pracovniky státu“. ${ }^{11}$ Situace ve vědě ve druhé polovině padesátých let však byla již odlišná od doby vzniku ČSAV. Novela zákona o vysokých školách z roku 1956 stanovila, že střediskem vědeckého života mají být vedle ústavů ČSAV i vysoké školy. Posílila se tak role vysokých škol jako vědeckých pracovišt', která měla právo zřizovat výzkumné ústavy, laboratoře atd. ${ }^{12}$ Když tedy bylo zřejmé, že egyptologické pracoviště zůstane i nadále (místo semináře ve formě ústavu) součástí univerzity, snažila se ČSAV přinejmenším zasahovat do jeho koncepce a př́pravy plánů práce. ${ }^{13}$ Otázka šíře vědeckého zaměření - zkoumání starověkého Egypta či komplexní výzkum arabských zemí (po vzniku SAR) ${ }^{14}$ od starověku po 20 . století - byla posledním pokusem ČSAV, respektive Orientálního ústavu, o „ovládnutí“ egyptologického bádání v Československu. Z následujících jednání a institucionálního zastoupení - jak na poradách, tak v různých návrzích a připomínkách - vyplývá, že se za celou kauzu nepostavilo prezídium ČSAV, ale pouze Orientální ústav, respektive jeho ředitel Jaroslav Prüšek. Orientální ústav neprošel právě nejlépe kádrovými posudky svých pracovníků a Průšek se asi

9 Vymezoval se tím pravděpodobně též vưči návrhu prof. Matouše, který v březnu 1956 navrhl za Katedru filologie a dějin Předního a Středního Východu a Indie filologické fakulty UK založení Ústavu filologie a dějin starověkého Orientu. Tento ústav měl být vytvořen sloučením semináře pro klínopisné bádání a dějiny starého Orientu a semináře egyptologického. Tento návrh zaslala katedra k vyjádření VIII. sekci ČSAV, ale nedochovalo se žádné další projednávání tohoto návrhu. Viz AAV ČR, fond VIII. sekce ČSAV, k. 19, i. č. 63.

10 Filologická fakulta Univerzity Karlovy vznikla ve školním roce 1952/1953 rozdělením filozofické fakulty na fakultu filozoficko-historickou a fakultu filologickou. V roce 1958/1959 vznikla opět jejich spojením filozofická fakulta. Egyptologický ústav byl tedy po svém vzniku v říjnu 1958 začleněn již do filozofické fakulty.

11 Sbirka zákonủ republiky Československé 1952, č. 52, Zákon o Československé Akademii věd.

12 Sbirka zákonů republiky Československé 1956, č. 46, Zákon, kterým se mění a doplňuje zákon o vysokých školách. Upřesnění v článku 16: „Pro vědeckou (uměleckou) a výzkumnou činnost a pro výchovu vědeckého (uměleckého) dorostu se na vysokých školách zřizují podle potřeb hospodářské a kulturní výstavby státu též vědecké a umělecké ústavy a vědecké laboratoře, a to jednak pro jeden nebo několik příbuzných oborů; mohou sloužit i několika katedrám, fakultám nebo vysokým školám. Vědecké ústavy a vědecké laboratoře jsou vědecko-výzkumná pracoviště vysokých škol; jejich zřizování upravují zvláštní předpisy." K této problematice viz např. studii František Morkes, Změny v postaveni a řizeni vysokých škol, in: Hana Barvíková - Marek Durčanský - Pavel Kodera (edd.), Věda v Československu v letech 1953-1963, Praha 2000, s. 53-65 (zvl. s. 61-62).

13 Sbirka zákonů republiky Československé 1952, č. 52, Zákon o Československé Akademii věd. „Akademie přispívá po vědecké stránce též k rozvoji vědecké činnosti veškerých ústavů do ní nezačleněných.“

14 SAR - Sjednocená arabská republika. Dne 22. února 1958 vytvořil Egypt unii se Sýrií (plánované připojení Jemenu se nakonec neuskutečnilo, Sýrie z tohoto svazku vystoupila v roce 1961, ale k přejmenování Egypta došlo až v roce 1971 (Egyptská arabská republika). 
oprávněně obával konkurence nového specializovaného pracoviště, jehož úzce zaměřený výzkum při každé př́ležitosti kritizoval.

V únoru a v březnu 1957 došlo $\mathrm{k}$ určitému posunu od návaznosti egyptologické práce na kulturní dohodu ke snaze zř́idit svébytné egyptologické pracoviště. Zbyněk Žába postupně vypracoval dva návrhy týkající se přímo založení egyptologického ústavu. Tomu však předcházelo jednání na MŠK, kde se sešli zástupci ČSAV, univerzity a ministerstva, aby připravili hlavní body návrhu, který měl být předložen vládě ke schválení. Na schůzi dne 8. března 1957 obhajoval Žába důležitost československé pomoci v Núbii a v zápisu z této porady zdůraznil i stanovisko ČSAV k celé problematice: „Pokud jde o stanovisko ČSAV, vyjádřil je na schůzce na ministerstvu školství a kultury dne 8. března 1957 mistoředitel Orientálního ústavu s. Dr. L. Zgusta: ČSAV uznává důležitost podaného návrhu, plně uznává, že Orientální ústav (jakož ani zádné jiné pracoviště Akademie) nemá egyptologii zastoupenou a že v Egyptě prováději výzkum domácí nebo zahraniční university. ČSAV se však domnivá, že by se v budoucnosti méla při Čsl. egyptologickém ústavu v Káhiře vytvořit sekce arabistiky a islámistiky; v tom prípadě však je tu Orientální ústav, který má pracovnika tohoto oboru, takže by snad mèl být Čsl. egyptologický ústav v Káhiře od začátku(tj. $i$ dokud by arabistika nebyla pripojena) zř̀zen pod aegidou ČSAV."15

Výsledkem tohoto jednání byla první verze projektu ze dne 14. března 1957, jež se dochovala v kopii rozpracované pro MZV. V ní byl hlavní důraz kladen jak na odůvodnění existence tohoto specializovaného pracoviště, tak, pravděpodobně pod vlivem tvrdého střetu názoru Z. Žáby s ČSAV, na jeho umístění. „Pokud jde ještě o otázku, která instituce by měla ústav prevevit, upozornil jsem na zmíněné schůzce na MŠK, že si v př́padě začlenění ústavu do ČSAV nedovedeme představit osobni postaveni našich egyptologü, z nichž neni nikdo zaměstnancem na pracovišti ČSAV. V Akademii jsou platy daleko vyšši než na universitě a to by vedlo $k$ velmi nezdravým třenicím, $k$ dyby členové ústavu byli placeni rũzné, nikoli podle svého výkonu, nýbrž podle stupnic obou institucí. S. Dr. Minařik z Akademie správně připomněl na zminéné schůzce na MŠK, že by príbráni egyptologů do Akademie naráželo na velké finančni obtiže." 16

Na základě předchozích jednání a připomínek byl po poradě na univerzitě vypracován druhý návrh. Ten byl společně s průvodními listy, ve kterých Žába upozorňoval na dosah svého návrhu a na nutnost rychlého vyř́zení, poslán i prezidentovi Antonínu Zápotockému a náměstkovi předsedy vlády Antonínu Kopeckému. ${ }^{17}$ Oba se k návrhu vyjádřili kladně, stejně jako rektor Univerzity Karlovy Miroslav Katětov a návrh koncepce vzniku egyptologického ústavu byla nakonec jednomyslně schválena dne 23. března 1957 na schůzce všech zainteresovaných stran ${ }^{18}$ pořádané na MŠK. Žába měl za úkol zapracovat další připo-

15 AČEgÚ, k. 1, I/10/1957. Návrh na zř́zení Československého egyptologického ústavu v Káhiře ze dne 14. 3. 1957, k posouzení pro ministerstvo zahraničních věcí s př́lohou návrhu zmiňující i schůzku ze dne 8. 3. 1958.

16 AČEgÚ, k. 1, I/10/1957. Návrh na zřízení Československého egyptologického ústavu v Káhiře ze dne 14. 3. 1957, k posouzení pro ministerstvo zahraničních věcí.

17 AČEgÚ, k. 1, č. j. I/15/1957. Návrh na zřízení Československého egyptologického ústavu Karlovy university v Káhiře ze dne 27. 3. 1957.

18 Archiv Akademie věd ČR (dále AAV ČR), fond Orientální ústav ČSAV, k. 15, i. č. 78. Návrh na zřízení Československého egyptologického ústavu Karlovy university v Káhiře ze dne 27. 3. 1957. „Tento předběžný návrh, vypracovaný na základě původního návrhu Dr. Zbyňka Žáby, docenta egyptologie Karlovy university, a přijatého s. ministrem školství a kultury Dr. Kahudou, náměstkem předsedy vlády s. Kopeckým a presidentem republiky s. Antonínem Zápotockým, byl jednomyslně schválen na schůzce, svolané ministrem školství a kultury dne 23. března 1957 za přítomnosti zástupců ministerstva školství a kultury Dr. M. Krásy, jenž 
mínky a poslat tento „definitivní“ návrh k připomínkování ČSAV, respektive Orientálnímu ústavu. ${ }^{19}$

Rozšířený a doplněný návrh na vznik egyptologického ústavu je datován dnem 27. března 1957. Zbyněk Žába původní návrh předělal a rozšriřil dle podnětů z ministerstva a dalších úradů a to především o širší badatelskou základnu - tedy o arabistické bádání. „Navrhovaný Československý egyptologický ústav Karlovy university v Káhiře by brzy po svém zřizeni zahrnul do oblasti svého bádáni o starověkém Egyptě $i$ bádáni o novějším Egyptě (arabistiku a islámistiku), jak vyplývá z toho, že Egypt je dnes arabským státem."20

Jako hlavní důvody vzniku ústavu uvedl Žába možnost účasti na akci UNESCO, jejíž splnění by pak československým egyptologům umožnilo pracovat v Egyptě na vlastní koncesi. Zatímco totiž převážně filologicky zaměřený Lexa pracoval s vydanými texty, Žába se profiloval též jako archeolog a jeho zájmem bylo získání vlastní dokumentace $\mathrm{k}$ hospodářským a společenským poměrům ve starověkém Egyptě, která by nebyla tvořena jen úzkým v cizině publikovaným výběrem. „Chceme-li prenést těžiště bádání na výzkum hospodářských a společenských poměrů ve starověkém Egyptě, narážime na neprekenatelnou překážku: jsme odkázáni na materiál, vybraný a zpracovaný ústavy západnich států, kde hlediska výběru publikovaného materiálu a ovšem i způsob zpracováni odporuji potřebám pokrokového bádání. Dosavadní pokusy o marxistický výklad dějin starého Egypta jasně ukazují, že máme nedostatek dílčich praci, které by vycházely z pưvodniho, nově zpracovaného materiálu." 21

Návrh navíc obsahoval velmi přehledně a důkladně vypracovaný odstavec o důvodech, proč by měl být ústav součástí filologické fakulty: „Vzhledem $k$ tomu, že 1. jediným pracovištěm československé egyptologie jest egyptologický seminár filologické fakulty Karlovy university, 2. tradice československé egyptologie, zvláště v Egyptě všeobecně známá a uznávaná, je nerozlučně spjata s Karlovou universitou, 3. egyptologického bádání se v Egyptě súčastňnji (sic) pouze university, at’ už domácí nebo zahraniční, 4. oba naši egyptologové, profesor Dr František Lexa a docent Dr Zbyněk Žába jsou zaměstnanci Karlovy university (profesor Lexa je akademik, avšak jeho pracovištěm je egyptologický seminár Karlovy university), 5. i pokud jde o budoucí rozšírení pracovní oblasti navrhovaného ústavu na vědni obor arabistiky, je arabistika i islámistika zastoupena největši měrou na Karlově universitě a to seminářmem filologie a dějin Předního východu (čtyřmi pracovníky, z nichž dva jsou učitelé jediného mladého pracovníka Orientálního ústavu ČSAV), 6. práce, které by se v rámci ústavu prováděly, jsou rázu převážně epigrafického a jen nepatrnou měrou archeologického (egyptské archeologii se ostatně soustavně vyučuje v naší republice právě jen v egyptologickém seminárí Karlovy university), je z těchto di̊vodů nejvhodnějš́ a také pro egyptskou stranu nejpríjatelnějši naši institucí Karlova universita, vjejímž rámci by se měl navrhovaný

schůzi předsedal, a s. Voženílkové, původního navrhovatele doc. Dr. Zbyňka Žáby, zástupce egyptologického semináře Karlovy university, ředitele tohoto semináře akademika Františka Lexy, zástupce rektorátu Karlovy university s. prorektora prof. Dr. B. Hejtmana, zástupce děkanátu filologické fakulty Karlovy university, vedoucího katedry filologie a dějin Předního Východu a Indie, prof. Dr. L. Matouše a zástupce Orientálního ústavu Československé akademie věd, vědeckého pracovníka akademie, Dr. Ivana Hrbka.“

19 AČEgÚ, k. 1, č. j. VI/1/1957. Československý egyptologický ústav v Káhiře. Přehled dosavadního jednání.

20 AAV ČR, fond Orientální ústav ČSAV, k. č. 15, i. č. 78. Návrh na zř́zení Československého egyptologického ústavu Karlovy university v Káhiře ze dne 27. 3. 1957.

21 Tamtéž. 
ústav uskutečnit." 22 Proč se zastřešující institucí měla stát právě Karlova univerzita, vyplývá z několika důvodů. Zbyněk Žába se pravděpodobně obával „rozplynutí“ egyptologického ústavu v rámci bádání o orientálních zemích, či připojení k Orientálnímu ústavu ČSAV, kde by ztratil své vedoucí postavení (od roku 1956 můžeme sledovat rostoucí vliv Zbyňka Žáby na vývoj egyptologie v Československu). Také si velmi dobře uvědomoval nutnost výchovy dalších egyptologů, aby se ústav mohl dále rozvíjet a žádné jiné podobné pracoviště, které by připravilo studenty $\mathrm{k}$ tomuto povolání, $\mathrm{v}$ Československu na univerzitě neexistovalo.

Orientální ústav, který následně, v dubnu 1957 posuzoval nové pracoviště za ČSAV, vznesl pravděpodobně nejzávažnější námitku, týkající se př́liš úzkého zaměření Egyptologického ústavu - jen na Egypt a navíc převážně jen na starověký Egypt. ${ }^{23}$ Naopak Orientální ústav se dle svých stanov věnoval studiu kultury, dějin, politického vývoje a jazyků Předního a Dálného východu bez časového omezení. Vytvoření nového, úzce zaměřeného ústavu pak pokládal za zbytečné třŕštění vědeckých sil a prridělovaných financí. Navrhoval vytvořit spíše pracoviště určené pro interdisciplinární práci, kde by své místo našli též arabisté, lingvisté či folkloristé, ale zároveň poukazoval na nevýhodnost vytváření dalšího pracoviště vedle Orientálního ústavu: „Jsme tedy přesvědčeni, že za dané situace by bylo pro naši vědu daleko výhodnější, kdyby se vláda rozhodla částku eventuálně prípravovanou pro nějaký speciálni ústav v Egyptě věnovati mimořádnému nákupu našich knižnich nauk, ev. realisaci studijnich cest do různých zemí Orientu [...]. Kromě toho je třeba uvážit, že ústav, jak jest projektován, jest tak nepatrný, že jest př́mo vyloučeno, aby dosáhl nějakých pozoruhodnějších úspěchü. “24

Jak již bylo několikrát zdůrazněno, Zbyněk Žába se od počátku zasazoval o to, aby byl ústav zř́zen v rámci Karlovy univerzity a ne jako součást ČSAV, což byla další podstatná námitka Orientálního ústavu. „Vycházíme-li pak z našich poměrư, konstatujeme, že podobný návrh je jednak neslučitelnýs postavením ČSAV jakožto orgánu vrcholného vědeckého, který organisuje na nejvyšši úrovni vědeckou práci. Jedině ČSAV svou rozsáhlou strukturou a svými rozsáhlými možnostmi může v budoucnu zajistit, aby se práce ústavu rádně vyvíjela do všech oblastí, jež budou shledány potřebnými (arabistika, archeologie, ethnografie atd.). Navrhujeme tedy, aby ev. egyptologický ústav v Káhiře byl součástí Československé akademie věd." 25

22 Tamtéž.

23 AAV ČR, fond Orientální ústav ČSAV, k. 8, i. č. 25. Vědecká rada - zápisy ze schůzí 1952-1964, zápis ze schůze vědecké rady Orientálního ústavu, která se konala dne 11. dubna 1957. V zápisu je načrtnutý oficiální postoj Orientálního ústavu vůči návrhu na vznik Československého egyptologického ústavu rozebraný dále v textu. O otázce zaměření egyptologického ústavu (,Když již by se vláda rozhodla podobný ústav zř́idit, je třeba důrazně upozornit na to, že jeho koncepce, tak jak je podána v návrhu Žábově, je nesmyslně úzká.“) a jeho možného začlenění do ČSAV (viz dále) bylo hlasováno a jediný hlas, který se vyslovil proti oběma bodům, patřil pravděpodobně egyptologu Lexovi. Důležitou výpověd' k těmto jednáním by měl též fond VIII. sekce v AAV C̆R, bohužel zápisy předsednictva VIII. sekce se pro roky1957 a 1959 zachovaly pouze torzovitě, rok 1958 chybí úplně.

24 AČEgÚ, k. č. 1, č. j. I/16/1957. Vyjádření Orientálního ústavu k návrhu Z. Žáby na zř́zení Československého egyptologického ústavu v Káhiře ze dne 6. 4. 1957, dochována jen část vyjádření. Další dokumenty k této problematice viz AČEgÚ, k. č. 1, č. j sine. Československý egyptologický ústav UK v Káhiře. Přehled dosavadního jednání; AAV Č R, fond Orientální ústav ČSAV, k. č. 15, i. č. 78. Návrh vypracoval z pověření sinologa, ředitele Orientálního ústavu Jaroslava Průška, orientalista Ladislav Zgusta. Vznikl na základě jednání schůze vědecké rady Orientálního ústavu. František Lexa, který se této schůze též účastnil, označil text Zgusty za nepřesný a mnohdy se odchylující od závěrů jednání vědecké rady Orientálního ústavu ze dne 11. dubna 1957.

25 AAV ČR, fond Orientální ústav ČSAV, k. č. 15, i. č. 78, vyjádření Orientálního ústavu k návrhu Zbyňka Žáby na zř́zení československého egyptologického ústavu, pro ministerstvo školství a kultury. 
Žába naopak kladl důraz na kontinuitu egyptologického semináře na filozofické fakultě i to, že on sám a František Lexa jsou jejími zaměstnanci. Akademie věd by navíc měla problém se začleněním nových pracovníků, nebot' jejich platy by byly vyšší než na univerzitě a akademie s tím ve svém rozpočtu nepočítala. ${ }^{26}$

Jistě též není bez zajímavosti, že na rok 1958 plánoval Orientální ústav založení své pobočky v Bratislavě, kterou by spolufinancovala SAV, a nemohl si dovolit odčerpávání financí určených na orientalistická studia pro zř́zení velmi úzce zaměřeného ústavu. ${ }^{27}$

Žábův návrh, připomínky Orientálního ústavu a Žábova a Lexova odpověd' byla zaslána kolegiu rektora a následně vědecké radě univerzity, kde byl návrh na založení egyptologického ústavu beze změn schválen. Žába byl poté vyslán na dvouměsíční cestu do Egypta (červen - červenec 1957), kde měl zjistit nutné finanční náklady na práci ústavu v Egyptě. V návrhu vypracovaném po návratu do Prahy už byla rozpracována i kalkulace finančních nákladů. Mnoho informací získal Žába na československém velvyslanectví v Káhiře a od egyptského egyptologa Selima Hasana. ${ }^{28}$ Jednalo se především o výpočty cen na nájem budovy, provoz archeologických prací, auta, platby členům expedice atd. Př́nosem této cesty do Egypta byl př́ílib Selima Hasana, že se Žába může od ledna 1958 účastnit prací Egyptského egyptologického ústavu na dokumentování egyptských starověkých památek. ${ }^{29}$

Po dalších úpravách, provedených společně s finančním oddělením MŠK, byl konečný návrh obsahující podrobné finanční náklady v záŕí 1957 postoupen kolegiu ministra školství. Dne 16. 9. 1957 kolegium MŠK projednalo a schválilo návrh na zřízení Československého egyptologického ústavu v Praze a v Káhiře (zároveň měl být tento návrh předložen vládě ke schválení a zajištěn jeho rozvoj na základě kulturních styků s Egyptem, stejně jako podmínky pro personální obsazení a provoz ústavu $)^{30}$ a v březnu 1958 pak Žába obdržel dopis z MŠK, že návrh schválila též vláda. ${ }^{31}$

Po schválení vzniku egyptologického ústavu v Československu bylo třeba zajistit též kladné vyř́izení ze strany egyptské. Žába přijal na dva roky místo profesora češtiny na Vysoké škole jazyků v Káhiře, aby svou osobní př́tomností v Egyptě jednání uspíšil: „O schválení návrhu naši vládou jsem podle pokynů MŠK v Káhiře spolupracoval na textu žádosti, kterou spolu s osobním listem s. min.[istra] Kahudy ministrovi výchovy v SAR a pak ministru nár. [odního] usměrnění, kterému př́slušejí v SAR památky a s nimi spojené instituce, odevzdal v mé př́tomnosti s. [vel]vyslanec 32 ČSR Dr. Arnošt Karpišek. Žádost

26 AČEgÚ, k. č. 1, č. j. I/10/1957. Poznámky k založení ČEgÚ pro MZV ze dne 14. 3. 1957 a VI/1/1957, Československý egyptologický ústav v Káhiře. Přehled dosavadního jednání, [záŕí] 1957.

27 Viz AAVČR, VIII. sekce, k. 3, i. č. 11 a k. č. 13, i. č. 28. Kabinet orientalistiky v Bratislavě v rámci SAV byl založen až o dva roky později v roce 1960 (o jeho vznik se především zasloužil orientalista a arabista Ján Bakoš) a fungoval do roku 1982, kdy byl zrušen. K jeho obnovení došlo až v roce 1990 a od roku 2005 pracuje pod názvem Ústav orientalistiky SAV.

28 Selim Hassan (1887-1961) - egyptský egyptolog, pracoval na univerzitě v Káhiře a vedl archeologické expedice po celém Egyptě. Viz Morris L. Bierbrier, Who Was Who in Egyptology, London 2012, s. $244-245$.

29 AČEgÚ, k. 1, č. j. I/23/1957. Ministerstvo školství a kultury, v Praze dne 5. 9. 1957. Materiál pro schůzi kolegia dne 12. 9. 1957. Návrh obsahuje informace dle Žábova textu z 27. 3. 1957, dále určuje počet zaměstnanců a minimální a maximální rozpočet egyptologického ústavu (pro 2-6 zaměstnanců).

30 Tamtéž. Ministerstvo školství a kultury, v Praze dne 5. 9. 1957. Materiál pro schůzi kolegia dne 12. 9. 1957.

31 AČEgÚ, k. 1, č. j. sine. Československý egyptologický ústav v Káhiře. Přehled dosavadního jednání.

32 Československo zř́ídilo v Egyptě velvyslanectví v roce 1956. 
byla datována 10. června 1958 a již 1. ledna 1959 přišla přiznivá odpovéd’ ministerstva zahr. vécí SAR."33

O složitém postavení Zbyňka Žáby svědčí i fakt, že v době, kdy již byl ústav schválen československou vládou, včetně jeho umístění na Filologické fakultě Univerzity Karlovy a rozpočtu, se v květnu 1958 sešla, asi ne náhodou v době Žábova zahraničního pobytu v Egyptě, komise katedry filologie a dějin Předního a Středního východu a Indie. ${ }^{34} \mathrm{Na}$ svém zasedání se usnesla, že vzhledem ke vzniku SAR je nutné pozměnit i původní náplň práce egyptologického ústavu, která by se měla rozšiřit i o zkoumání dalších států, tedy Sýrie a Jemenu. Zajímavé je, že téměř polovina ze dvou stran strojopisu této zprávy obsahuje opět velmi argumentační pasáž o nutnosti spojení takovéhoto ústavu s Karlovou univerzitou, která jako jediná může zastřešit výzkum v oblasti egyptologie, arabistiky a starověkého Předního východu. Plánované rozš́iření působnosti ústavu však bylo navrženo až pro dobu, kdy již bude ústav i v Egyptě schválen, aby nedošlo ke zbytečným časovým průtahům. Zbyněk Žába se zaštítil československým velvyslanectvím v Egyptě i názory kolegů egyptologů a návrh jednoznačně odmítl s tím, že by nebyl kladně přijat egyptskou stranou a navíc zdůraznil, že rozpočet s ničím takovým nepočítal. „Podle souhlasného názoru všech jsem pak vypracoval svou odpověd, ve které jsem poukázal, že zcela bez ohledu na to, že můj návrh v koncepci dojednané na MŠK byl již schválen vládou a přiděleny mu finanční prostředky, nedostačujici ke krytí nějakého širšiho návrhu, politická situace v SAR vylučuje zř́zeni takového prvniho obrovitého ústavu, a to proto, že Sýrie je provincie obklopená územím neklidu, administrativni spojeni Egypta a Sýrie se plánuje na nejméně dalšich 5 let a již nyni se ví, že tento termín nebude stačit, památkové služby jsou dosud rozděleny, obě území jsou od sebe tak vzdálena a bez přimého spojení kromé po moři a letecky." 35

Ačkoli se požadavek fakulty může zdát zbytečně maximalistický, vycházel pravděpodobně z obavy, aby se v rámci SAR neprosadily se svými vědeckými projekty též Orientální ústav či Archeologický ústav - tedy ústavy ČSAV.

Československý egyptologický ústav v Praze byl zrrízen, ve svém původním rozsahu vědeckého zaměření, dne 1. ř́ina 1958 na základě usnesení vlády ČSR a jeho ředitelem byl zvolen František Lexa. ${ }^{36}$ Československý egyptologický ústav v Káhiře vznikl dne

33 AČEgÚ, k. 1, č.j. sine 1959. Zprávy Zbyňka Žáby z jeho pobytu v SAR 1957-1959. Administrativní dokumenty ohledně jeho vyslání a návratu z Káhiry viz AUK, fond Filozofická fakulta UK, osobní spis Zbyněk Žába, č. 662 , oddíl rok 1957 a 1959.

34 AČEgÚ, k. 1, č. j. I/27/1957 (špatné číslování dokumentu, má být rok 1958), Připomínky k návrhu akademika Františka Lexy a doc. dr. Zbyňka Žáby na vytvoření Egyptologického ústavu Karlovy University ze dne 2. května 1958, pro Úřad předsednictva vlády. „Komise dospěla k názoru, že současná politická situace na Předním Východě, především pak vznik Sjednocené arabské republiky si př́ímo vynucuje změnu původního návrhu. Sjednocením Egypta a Sýrie a federativním připojením Jemenského království k SAR, dostávají se do pole působnosti navrhovaného střediska čs. vědy v Egyptě, podléhajícího Karlově Universitě, rozsáhlé kulturní oblasti, jejichž průzkum má na Filologické fakultě K. U. vynikající tradici. Jsou to vedle oblasti Egypta oblast kultury mesopotamské, pokud se zachovala v Sýrii, a oblast Jižní Arábie.“

35 AČEgÚ, k. 1, č. j. VI/1/1957. Československý egyptologický ústav v Káhiře. Přehled dosavadního jednání. A dále dva přehledy jednání o vzniku ústavu z roku 1959, bez přesné datace a čísel jednacích. Založeny předběžně $\mathrm{k}$ dokumentům $\mathrm{z}$ roku 1959.

36 AČEgÚ, k. 1, č. j. sine. Sdělení rektorátu University Karlovy v Praze o založení Československého egyptologického ústavu v rámci filosofické fakulty ze dne 8. 8. 1959, pro děkanát Filosofické fakulty UK. Systemizace ústavu byla schválena dekretem ministerstva školství a kultury ze dne 27. ledna 1959, č. j. 3116/59-E/1. Organizační řád byl schválen dekretem ministerstva školství a kultury ze dne 18. června 1959, č. j. 27538/59-III/1. 
20. května $1959 .{ }^{37}$ Do Káhiry odjela delegace Univerzity Karlovy ${ }^{38}$ vedená děkanem Júliem Dolanským, členy byli František Lexa a Zbyněk Žába. Delegace během svého pobytu vykonala řadu oficiálních návštěv u vládních i vědeckých představitelů Egypta a dne 20. května na slavnostní recepci na velvyslanectví ohlásil československý velvyslanec Arnošt Karpíšek založení Československého egyptologického ústavu v Káhiře. Recepce se zúčastnili zástupci vlády SAR, většina egyptských a mnoho zahraničních egyptologů, kteří zastupovali všechny hlavní vědecké zahraniční egyptologické instituce té doby. V projevu velvyslance bylo slíbeno zahájení prací v Egyptě už v zimě na přelomu let 1959/1960 a díky obětavé práci Zbyňka Žáby byla již od 1 . ledna 1959 najata vila v Káhiře, která se na dlouhou dobu stala střediskem československých egyptologů při jejich práci v Egyptě.

Na počátku listopadu 1959 se Zbyněk Žába vrátil z Egypta ${ }^{39}$ a teprve v roce 1960 bylo vyřešeno jmenování prvních členů egyptologického ústavu, aby mohli začít s vytyčenými úkoly. Dne 13. února 1960 zemřel František Lexa a od 15. února 1960 se Žába prozatímně ujal vedení ústavu, úředně byl vedením ústavu pověřen dne 7. března 1960 rektorem univerzity.

Vědecká rada ústavu, navržená v únoru 1960 děkanem FF UK a schválená v březnu 1960, ${ }^{40}$ zajišt'ovala př́pravu vědeckých a pracovních plánů egyptologického ústavu. Členy se stali pracovníci egyptologického ústavu - egyptolog Zbyněk Žába, arabisté Felix Tauer, ${ }^{41}$ Karel Petráček, ${ }^{42}$ dále za FF UK Jiř́ Frel, ${ }^{43}$ Otakar Nahodil, ${ }^{44}$ Jaroslav Varcl, ${ }^{45}$ Oldřich Říha ${ }^{46}$ a za dalš́ instituce byli jmenováni Jaroslav Prưšek, ${ }^{47}$ ředitel Orientálního

37 AČEgÚ, k. 1, č. j. sine. Československý egyptologický ústav UK v Káhiře. Přehled dosavadního jednání. Dne 1. ledna 1959 zaslalo ministerstvo zahraničních věcí SAR dopis československému velvyslanectví v Káhiře, ve kterém byl potvrzen souhlas se zř́zením československého egyptologického ústavu v Káhiře. Dále viz Adéla MaскоvÁ, Vznik Československého egyptologického ústavu, Nový Orient 1, 2006, s. 57-60; Eugen Strouhal, Zahájení československých archeologických výzkumů v Egyptě v roce 1961, in: H. Barvíková - M. Duurčanský P. Kodera (edd.), Věda v Československu 1953-1963, s. 399-413.

38 Viz A. Jưnová Macková, Druhá cesta Františka Lexy, s. 325-348.

39 V roce 1959 byl konečně jmenován profesorem egyptologie. Podrobněji viz AUK, fond Filozofická fakulta UK, osobní spis Zbyněk Žába, č. 662, oddíl rok 1959.

40 Se všemi jmenovanými již návrh z února 1960 počítal. Viz AUK, fond Filozofická fakulta UK, Egyptologický ústav, k. 688, Děkanát FF pro rektorát UK, návrh na jmenování vědecké rady Československého egyptologického ústavu ze dne 23. 2. 1960, a Zbyněk Žába návrh vědecké rady II. pro děkanát FF ze dne 7. 3. 1960 s příipisem, že vědecká rada byla schválena dne 8. 3. 1960, tento návrh byl rozšířen o historika Říhu.

41 Felix Tauer (1893-1981) - český orientalista, filolog a historik Blízkého východu, člen Orientálního ústavu. Viz Jan FILIPSKÝ a kol., Kdo byl kdo - Čeští a slovenští orientalisté, afrikanisté a iberoamerikanisté, Praha 1999 , s. 485-485.

42 Karel Petráček (1926-1987) - český arabista, semitista, islamista a afrikanista, vystudoval též egyptologii, působil na katedře Předního východu a Indie, částečně též v Československém egyptologickém ústavu. Viz J. FiLIPSKÝ a kol., Kdo byl kdo, s. 380-386.

43 Jiř́i K. Frel (1923-2006) - klasický archeolog, v letech 1967-1969 profesor na FF UK, v roce 1969 emigroval do USA, učil na Princeton University, později pracoval jako kurátor v Metropolitan Museum of Art a v Paul Getty’s Museum. Viz Josef Tomeš a kol., Český biografický slovník XX. století, I, Praha 1999, s. 339.

44 Otakar Nahodil (1923-1995) - český etnolog a kulturolog, v letech 1950-1962 působil na FF UK, v roce 1966 emigroval do Německa. Viz J. TomEš a kol., Český biografický slovník XX. století, III, Praha 1999, s. 423.

45 Ladislav Varcl (1909-1980) - klasický filolog, působil na FF UK od roku 1947, od roku 1960 profesor, v letech 1963-1980 vedoucí Kabinetu pro studia řecká, římská a latinská ČSAV. Viz J. TomEŠ a kol., Český biografický slovník XX. století, II, Praha 1999, s. 430.

46 Oldřich Říha (1911-1974) - český historik, jeden ze zakladatelů českého marxistického dějepisectví, od roku 1949 profesor všeobecných dějin novověku na FF UK, od roku 1970 ředitel Ústavu českých a světových dějin ČSAV. Viz J. TOMEŠ a kol., Český biografický slovník, III, s. 82

47 Jaroslav Průšek (1906-1980) - český sinolog, člen Orientálního ústavu, po válce se stal jeho ředitelem a po založení ČSAV vedl VIII. sekci - filologickou. Viz J. FILIPSKÝ a kol., Kdo byl kdo, s. 406-407. 
ústavu ČSAV, Erich Herold, ${ }^{48}$ ředitel Náprstkova muzea, a Ivan Hrbek, ${ }^{49}$ vědecký pracovník Orientálního ústavu ČSAV. Zbyněk Žába byl jmenován členem vědecké rady Orientálního ústavu.

Z tohoto stručného výčtu struktury řízení egyptologického ústavu je jasné propojení s Orientálním ústavem ČSAV, který si tak zachovával alespoň částečný dohled nad prací egyptologů. Sledování jejich práce, respektive kritika jejich prvních neúspěchů od ř́ijna 1958 do počátečních měsíců roku 1960 se plně projevila už na třetím sjezdu orientalistů v Liblici dne 21. prosince 1959, tedy v době, kdy ústav již formálně fungoval, ale nebyli jmenováni vědečtí pracovníci, neexistovala vědecká rada a nekonala se plánovaná expedice do Egypta, kdy byla od zář́ 1959 najata vila v Gíze. V lednu 1960 pak Z. Žába musel objasňovat kolegiu děkana, proč došlo ke značnému zdržení počátečních prací ústavu. Existenci vědeckého pracoviště uhájil. ${ }^{50}$

V únoru 1960 však celý spor pokračoval a otevřel se v plné šíri na schůzce MŠK, jejímž programem byla porada o Československém egyptologickém ústavu. ${ }^{51}$ Jaroslav Průšek, který zastupoval Orientální ústav, respektive akademii věd, opět zdůrazňoval koncepci širokého zaměření egyptologického ústavu, tedy koncepci, na které trvala akademie věd. „Jestliže však vláda rozhodla EÚ zř́dit, je vidět, že celé věci přikládá velký význam, a proto je třeba vytvořit spoluúčast všech instituci, které mohou přispět $k$ zdárnému chodu ústavu a mluvit otevřeně o jeho konečné koncepci. Opakuje [J. Průšek] znovu, že ústav musí mít $v$ prvé radě široké zaměrení na celý Předni východ, tj. komplexni studium dějin, života a kultury Předního východu, teprve potom studium egyptologicko-archeologické." 52 Akademie věd se jasně stavěla do pozice vědecké instituce, jejiž radou (nařízením) se měl egyptologický ústav řídit již při prvních návrzích své činnosti a rozsahu práce. Jaroslav Průšek si však neodpustil ani poznámku týkající se nově jmenovaného ředitele ústavu, Zbyňka Žáby, který podle něj nebyl dostatečně vhodný kandidát pro ústav zaměřený na celý Blízký východ.

Koncepce propagovaná akademií věd se však př́liš nekryla s postojem filozofické fakulty. Ta sice též podporovala širší zaměření egyptologického ústavu, ale zároveň plně souhlasila s názorem Z. Žáby, že $\mathrm{v}$ danou dobu by široce zaměřené výzkumné pracoviště nemuselo být egyptskou stranou podporováno. Tento požadavek katedry filologie a dějin Předního a Středního východu a Indie se tedy promítl v organizačním řádu egyptologického ústavu v mnohem neurčitějším vyjádření: ,1) Úkolem ústavu jest: a) pěstovat a organisovat bádáni $v$ těchto vědních oborech: v egyptologii, egyptské archeologii, arabistice, islamistice a podle možnosti podporovat i ostatni přibuzné vědni obory. [...] 2) Ústav bude

48 Erich Herold (1928-1988) - český indolog, afrikanista, muzeolog, v letech 1952-1959 působil v Orientálním ústavu, poté v Náprstkově muzeu, které několik let vedl. Stanislav BROUČEK - Richard JEŘÁBEK, Lidová kultura. Národopisná encyklopedie Čech, Moravy a Slezska. Biografická část, Praha 2007, s. 71-72.

49 Ivan Hrbek (1923-1993) - český arabista, islamista, afrikanista, od roku 1953 působil v Orientálním ústavu, přednášel na UK. Viz J. FILIPSKÝ a kol., Kdo byl kdo, s. 192-196.

50 AČEgÚ, k. 1, č. j. I/35/1960. Referát Z. Žáby O Československém egyptologickém ústavě Karlovy university v Praze a Káhiře, podklady na schůzku kolegia děkana ze dne 26. ledna 1960.

51 AAV ČR, fond Orientální ústav ČSAV, k. 15, i. č. 78. Zápis z porady o Československém egyptologickém ústavě v Káhiř̌e 23. 2. 1960 na MŠK.

52 AAV ČR, fond Orientální ústav ČSAV, k. 15, inv. č. 78. Zápis z porady o Československém egyptologickém ústavě v Káhiře 23. 2. 1960 na MŠK. 
spolupracovat i s ostatními ústavy a katedrami Karlovy university, a dalšimi československými vědeckými institucemi a se společnostmi popularizujícími vědu. "53

Organizační ŕád egyptologického ústavu však také vznikl jen v rámci filozofické fakulty a explicitně nabízel spolupráci pouze ústavům a vědcům z Karlovy univerzity. Jaroslav Průšek si tento dokument vyžádal teprve po schůzce na MŠK, do té doby neměl tušení, že již byl na fakultě schválen. Jakkoli neurčité naznačení možnosti širšího bádání v zemích Orientu tento dokument obsahoval, MŠK však pravděpodobně stačilo, aby byly ukončeny jakékoli další diskuze o nutnosti svazovat egyptologický ústav nařízeními jiných vědeckých institucí. Další porada konaná na MŠK dne 4. března 1960 jen projednala organizační ŕád, rozhodla o nutnosti širšího zaměření bádání v SAR (ovšem s tím, že nejdůležitějším úkolem je spolupráce na mezinárodní akci UNESCO v Núbii), a jednala též o návrhu vědecké rady ${ }^{54}$ Rozšíření vědecké rady o Průška, Hrbka a Herolda, jež bylo výsledkem obou těchto schůzí, mělo být dostatečnou zárukou pro akademii věd, která tak získala dohled na další zaměření a profilování egyptologického ústavu. ${ }^{55}$

Koncem roku se naopak egyptologové velmi dobře prripravili na výroční setkání orientalistů dne 15. prosince $1960 .{ }^{56}$ Ve svém referátu profesor Žába vysvětlil problémy, jež nastaly po založení egyptologického ústavu v roce 1959, a naopak značně vyzdvihl své zásluhy za období, kdy se postavil do čela ústavu. Ústav byl obsazen vědeckými pracovníky, zahájil svou vědeckou činnost v Praze i v Káhiře, úspěšně zakončil první expedici v Egyptě a připravil vše pro následující pětiletou kampaň mezinárodního výzkumu starověkých památek v Núbii. Na konci roku 1960 se tak Československý egyptologický ústav etabloval jako úspěšně se rozvíjející vědecké pracoviště v rámci Univerzity Karlovy a toto postavení si udržel až do normalizace, kdy byl na téměř čtyři roky (1970-1974) zrušen, respektive začleněn do katedry filologie a dějin Předního a Středního východu a Indie.

53 Tamtéž. Zápis z porady o Československém egyptologickém ústavě v Káhiře 23. 2. 1960 na MŠK. Př́loha Organisační ŕád Ćeskoslovenského egyptologického ústavu University Karlovy.

54 AUK, fond Filozofická fakulta, Egyptologický ústav, k. 688, Zápis z porady na MŠK dne 4. března 1960, MŠK pro děkanát FF dne 12. března 1960.

55 Změna př́stupu k svébytnosti Československého egyptologického ústavu se pak projevila při další schůzi MŠK v dubnu 1960, kdy byly kontrolovány závazky, tzn. jmenování vědecké rady, prŕíprava expedice, vyhlášení konkurzu na vědecké pracovníky atd., ale již nikdo nezpochybňoval práci ústavu a jeho ředitele. Viz AUK, fond Filozofická fakulta, Egyptologický ústav, k. 688, Zápis z porady na MŠK konané dne 29. dubna 1960.

56 AČEgÚ, k. 1, č. j. XIV/8/1960. Referát Z. Žáby o činnosti Československého egyptologického ústavu Karlovy university, přednesen dr. J. Novotným na sjezdu orientalistů v Liblicích dne 15. 12. 1960. Dále viz AUK, fond Filozofická fakulta, Egyptologický ústav, k. 688, Zpráva o účasti egyptologického ústavu na konferenci orientalistů v Liblicích ze dne 8. prosince 1960, Z. Žába pro děkanát FF. 


\title{
Die Entstehung des Tschechoslowakischen Ägyptologischen Instituts. Konfrontation zwischen Akademie und Philosophischer Fakultät der Karlsuniversität
}

\author{
ZUSAMMENFASSUNG
}

Die Studie präsentiert die mit der Gründung des Tschechoslowakischen Instituts für Ägyptologie zusammenhängenden Verhandlungen in ihrer Entwicklung ab 1956, als František Lexa und Zbyněk Žába als Mitglieder einer tschechoslowakischen Kulturdelegation nach Ägypten reisten und dort über die Gründung eines ägyptologischen Instituts verhandelten. Nach dem positiven Echo ägyptischerseits stellte Z. Žába beim tschechoslowakischen Ministerium für Schulwesen und Kultur den Antrag, im Rahmen der geplanten kulturellen Zusammenarbeit mit Ägypten ein Institut für Ägyptologie zu gründen. Zu diesem Vorschlag nahm auch die Tschechoslowakische Akademie der Wissenschaften bzw. ihr Orientalisches Institut Stellung, das versuchte, ein ägyptologisches „Konkurrenz"-Unternehmen dem Orientalischen Institut der Akademie einzugliedern. Dies gelang nicht, doch wurde auf Drängen des Orientalischen Instituts die Ausrichtung des Instituts für Ägyptologie um Arabistik erweitert. In dieser Form wurde das Tschechoslowakische Ägyptologische Institut dann 1958 der Philosophischen Fakultät der Karlsuniversität eingegliedert und 1959 auch seine Zweigstelle in Kairo gegründet. Zum ersten Direktor des neu gegründeten Instituts wurde František Lexa ernannt, nach dessen Tod Anfang 1960 trat dann Zbyněk Žába seine Nachfolge an.

Deutsche Übersetzung Wolf B. Oerter

Adéla Jionová Macková

Masarykův ústav a Archiv Akademie věd $\check{C} R$, v. v. i.

mackovija@volny.cz 